\title{
SKELETAL STRESS MARKERS AND SUBSISTENCE STRATEGY IN PREHISTORIC CHILEAN POPULATIONS OF THE SEMI-ARID NORTH
}

\author{
MARCADORES DE ESTRÉS ESQUELÉTICO Y ESTRATEGIA DE SUBSISTENCIA \\ EN POBLACIONES CHILENAS PREHISTÓRICAS DEL NORTE SEMIÁRIDO
}

\author{
Elizabeth A. DiGangi ${ }^{1}$ and Ariel Gruenthal-Rankin ${ }^{1}$
}

\begin{abstract}
Human skeletal remains from prehistoric Chile's semi-arid north were analyzed using the Western Hemisphere Health Index to ascertain if subsistence change from gathering/hunting to agriculture was accompanied by a decline in physiological stress as measured by common skeletal stress markers for these coastal populations. Individuals analyzed dated to the Archaic (c. 7000 BC-200 AD, n=95) and Diaguita (c. 1000-1536 AD, n=75) periods. The Archaic individuals practiced gathering and hunting subsistence, relying on desert and ocean resources. The Diaguita practiced a subsistence strategy including agriculture, food collecting from the Pacific, and camelid pastoralism. As per health index methodology, seven indicators were scored (stature, linear enamel hypoplasia, dental disease, cribra orbitalia/porotic hyperostosis, infection, degenerative joint disease, and trauma). Results indicated equal health index values for both samples, although there were some differences in individual indicator values. The risk of having any pathology did not increase with age-at-death. Essentially, health as measured by common stress markers did not vary substantially after subsistence change. Such results are further evidence that the hypothesis of a health decline after subsistence change to agriculture is not always demonstrated, and it is important to elucidate what buffering variables beyond diet, to include cultural adaptations, may be at play.
\end{abstract}

Key words: Norte Chico, Western Hemisphere Health Index, Chilean Diaguita.

Los restos de esqueletos humanos del norte semiárido de Chile prehistórico fueron analizados utilizando el Índice de Salud del Hemisferio Occidental para comprobar si el cambio de subsistencia de la recolección/caza a la agricultura estuvo acompañado por una disminución en el estrés fisiológico de acuerdo con la medición realizada por marcadores de estrés esquelético comunes para estas poblaciones costeras. Los individuos analizados datan de los periodos Arcaico (c. 7000 AC-200 DC, $n=95)$ y Diaguita (c. 1000 - 1536 DC, $n=75)$. Los individuos Arcaicos practicaron la recolección y la caza para subsistir, dependiendo de los recursos del desierto y del océano. Los Diaguita practicaron una estrategia de subsistencia que incluía la agricultura, la recolección de alimentos del Pacífico y el pastoreo de camélidos. Según la metodología del índice de salud, se midieron siete indicadores (estatura, hipoplasia lineal del esmalte, enfermedad dental, cribra orbitalia/hiperostosis porótica, infección, enfermedad degenerativa de las articulaciones y trauma). Los resultados dieron valores de índice de salud iguales para ambas muestras, aunque hubo algunas diferencias en los valores del indicador individual. El riesgo de padecer cualquier patología no aumentó con la edad al momento de la muerte. Esencialmente, la salud medida por los marcadores de estrés comunes no varió sustancialmente después del cambio de subsistencia. Tales resultados constituyen evidencia adicional de que no siempre se demuestra la hipótesis de un deterioro en la salud después del cambio de subsistencia a la agricultura, y de que es importante dilucidar qué variables amortiguadoras más allá de la dieta, para incluir adaptaciones culturales, puedan estar en juego.

Palabras claves: Norte Chico, Índice de Salud del Hemisferio Occidental, Diaguita.

The impact of subsistence transitions on human health has been an area of interest for bioarchaeologists for decades (e.g., Cohen and Armelagos 1984; Cohen and Crane-Kramer 2007; Pinhasi and Stock 2011; Steckel and Rose 2002). The transition to agriculture among populations has been treated extensively in the literature, with early works proposing benefits associated with reliable food sources, increased free time, and decreased physiological stress (Childe 1951; Cohen 1977). However, a wealth of bioarchaeological and ethnographic evidence since that time has demonstrated that the relationship between agriculture and well-being is far more complex than first imagined (Cohen and Armelagos 1984; Cohen and Crane-Kramer 2007; Lee and DeVore 1976). Monocrop diets and those limited in variety, which are often associated with intensive agriculture, have received

\footnotetext{
${ }^{1}$ Department of Anthropology, Binghamton University, 4400 Vestal Parkway East Binghamton, NY 13902 USA. digangi@binghamton.edu; agruent1@binghamton.edu
}

Recibido: mayo 2018. Aceptado: mayo 2019. 
a substantial amount of attention due to their impacts on overall nutrition and immune function (Buikstra 1992; Cohen 1989; Larsen 1995; Scrimshaw et al. 1968). Mixed subsistence strategies, and the incorporation of marine resources in particular, have been suggested and demonstrated to be a means of buffering the physiological impact of agricultural transitions in both prehistoric and modern contexts (Gómez and Novellino 2011; Tucker et al. 2010; Watson et al. 2010).

A complex picture of mixed subsistence strategies in the Americas has emerged through the synthesis of isotopic analysis and paleopathological data (Larsen 2015). For example, biochemical analyses of mixed subsistence populations in Panama and Costa Rica have revealed variation in the relative contributions of both marine and agricultural resources, though neither category was consumed to the exclusion of the other (Norr 1991). An analysis of the frequency of porotic hyperostosis, linear enamel hypoplasia, and infection among these individuals indicated that stress lesions could not be sufficiently explained by diet alone. Norr (1991) proposed that physiological stress markers, including porotic hyperostosis, linear enamel hypoplasia, and infection may have stemmed from an interplay of subsistence strategy and other factors including settlement type, geography, and sanitation. Further, Watson et al. (2013) note that along the Andean coast, early attempts at agricultural food production were associated with an increase in reliance on marine foraging. Studies of oral health in northern Chile demonstrate that relative contributions of marine and agricultural resources vary by site, with a heavier reliance on agriculture associated with distance from the coast and increased frequency of caries and tooth loss (Watson et al. 2010). It becomes clear that local environmental and cultural adaptations, including implementation of mixed subsistence strategies, play a significant role in the resulting "health" of a population.

This study examines skeletal samples from coastal populations of the semi-arid North of prehistoric Chile. Samples date to the Archaic (c. 7000 BC to AD 200) and Diaguita periods I, II, and III (c. 1000-1536 AD), which span a time of transition from maritime food collecting (Archaic) to mixed subsistence of agriculture, marine foraging, and pastoralism (Diaguita). These groups have been chosen to characterize the role that marine resource exploitation plays in agricultural transition and physiological stress. It is hypothesized that sustained marine foraging will buffer individuals from stress typically associated with intensifying agriculture.

\section{Health, Stress, and the Osteological Paradox}

Authors have previously discussed the importance of clarifying between the terms health and stress in bioarchaeology (McIlvaine and Reitsema 2013). Scholars emphasize that what we really are able to discern is not health per se, as health encompasses more than just lack of disease, and includes measures such as overall well-being (Reitsema and McIlvaine 2014; Temple and Goodman 2014). Our interpretation of health is complicated by bias due to selective mortality, as those individuals who have active lesions are typically represented in a higher proportion than would be seen in the living population (part of the osteological paradox) (Wood et al. 1992). Additionally, evidence of chronic illness indicates survival through acute phases of stress, suggesting that individuals who look ill skeletally may in fact be healthier than those without lesions. It is therefore suggested that stress, or indications of some physiological disruption that are recorded on the skeleton, may stand in as proxy for one aspect of health (Reitsema and McIlvaine 2014).

\section{The Health Index}

Health indices, constructed from numerous indicators related to both stress and well-being, have been proposed as a means of addressing the health/stress dilemma, as well as the osteological paradox (Marklein et al. 2016; Steckel et al. 2002a; Steckel et al. 2019). This is because indices can incorporate life expectancy for examined populations and mortality rates, as well as multiple indicators of stress (Steckel et al. 2002a).

One such index, devised to elucidate aspects of health through the examination of skeletal stress markers, is the Western Hemisphere Health Index (WHHI, Steckel et al. 2002a). For this study, the WHHI is used to build a more comprehensive view of well-being for populations in Chile's semi-arid north. This method was chosen given the inherent value of comparing the results for the semi-arid north with the results for 65 sites in the Americas included in Steckel and Rose's The Backbone of History (2002), several of which are also coastal South American sites.

The variables included in the WHHI were chosen because they fit into categories having a bearing on health (i.e., age-at-death, trauma, pathology, linear enamel hypoplasia, etcetera) in order to set up a meaningful way to compare studies across populations (Steckel et al. 2002a). In addition, the variables chosen have all been shown in multiple studies to impact health and well-being, insofar that they are markers of stress suffered by an individual during life (Goodman and Martin 2002). The stress model set forth by Goodman et al. (1984) as cited in Goodman and Martin (2002) includes environmental factors, such as parasites and climate, the effect of culture as a buffer against various stressors, and host resistance factors. While stress cannot be measured per se, skeletal markers that record instances of stress, 
such as linear enamel hypoplasia, can be useful in assessing the severity and amount of stress to which an individual was subjected over their lifetime (Goodman and Martin 2002). A major benefit to the WHHI methodology is in its comparative value, allowing the identification of trends and patterns seen between and even within populations.

\section{Archaeological Context}

\section{Location and climate}

The semi-arid north of Chile is located between latitudes 26 and 33 degrees south, physically spanning about 630 kilometers from north to south, and includes part of the Atacama, Coquimbo, and Valparaíso regions (Maldonado et al. 2016; Niemeyer and Cereceda 1983; Niemeyer et al. 1989). Its boundaries are the Pacific Ocean to the west, the Andes Mountains to the east, the Salado River to the north, and the Aconcagua River to the south (Figure 1).

The Pacific coast along this part of South America is one of the most productive ecosystems in the world given the effects of the Humboldt Current, allowing for increased nutrients in the water (Grosjean et al. 2007; Muñoz 2004). The high solar radiation coupled with the high nutrient level and upwelling currents lead to a proliferation of marine flora and fauna, and therefore, this area has been attractive to human settlement for millennia (Ampuero 1994; Muñoz 2004). With the exception of periodic El Niño climate events, this marine ecosystem represents a stable and predictable subsistence resource (Arriaza et al. 2001; Grosjean et al. 2007; Moseley 1999), providing an abundant source of mollusks, fish, sea birds, and marine mammals.

\section{Regional Prehistory Background}

\section{Archaic period}

The beginning of the Archaic Period in northern Chile is marked by the extinction of large mammals such as the mastodon, and dates to c. $7000 \mathrm{BC}$ to $\mathrm{AD}$ 200 (Kuzmanic and Castillo 1986). The new postglacial environment spurred a reorganization of subsistence, technology, and social organization (Ampuero 2010; Bogucki 1999; Méndez et al. 2016). Archaic peoples were essentially food collectors who migrated seasonally following guanaco herds (Ampuero 1986; López et al. 2016). In general, Archaic populations emphasized seasonally abundant resources and foods that could be stored (Bogucki 1999), including a variety of marine and terrestrial animals. The importance of marine subsistence is underscored by the presence of an abundance of fishing tools such as shell and cactus spine hooks, fish nets, and harpoons (Bird 1943; Grosjean et al. 2007; Muñoz 2004; Kuzmanic and Castillo 1986). In addition, trace element analysis of barium and strontium concentrations in remains from the Archaic period support a largely marine-based diet (Rosado 1994).

\section{Ceramic period}

Recent research focused on late hunter-gatherers has begun to question the traditional model that states hunting and gathering led directly to sedentary agriculture in the semi-arid North (Méndez et al. 2009; Troncoso et al. 2016b). The Ceramic period, consisting of the El Molle, Las Animas, and Diaguita cultures, began with evidence of incipient horticulture and llama domestication (Ampuero 1994; Niemeyer et al. 1989), although recent studies have emphasized the continuation of a hunting and gathering tradition (e.g., Becker et al. 2015). Scholars have documented an increasing orientation toward pastoralism, in addition to continuation of incipient horticulture, fishing, hunting and gathering (Ampuero 1994; Castillo 1989).

The Diaguita were the last indigenous culture to populate the semi-arid north before the reach of the Inka Empire into this region in the $15^{\text {th }}$ century and later, the arrival of Spanish conquistadors in the $16^{\text {th }}$ century. Archaeologists divide the Diaguita into three phases, with dates for Diaguita I and II of 1200-1470 AD, and Diaguita-Inka of 1450-1536 AD (Ampuero 1989; Troncoso et al. 2016a). Archaeological evidence suggests that subsistence was on three fronts: (1) maize-beanssquash agriculture, (2) maritime food collecting, and (3) pastoralism with domesticated llamas or guanacos (Ampuero 1994; Quevedo et al. 1982; Troncoso 1998). In addition, recent stable isotope evidence indicates that maize was not relied upon as a main dietary staple to the extent that it was in other areas (Alfonso-Durruty et al. 2016).

The Diaguita culture, as recognized archaeologically, ended abruptly with the claiming of the semi-arid north for Spain by conquistadors in AD 1537 (Ampuero 1994).

\section{Previous work}

Rosado (1994, 1998) carried out trace element analysis on strontium and barium in skeletal remains from Archaic and Diaguita samples, confirming archaeological evidence indicating a diet principally of marine resources for Archaic peoples, and a triad subsistence of agriculture/pastoralism/maritime food collecting for the Diaguita. She found that the Archaic peoples subsisted on a significantly higher amount of marine resources than did the Diaguita, and that the Diaguita focused on a combination of terrestrial and marine resources (Rosado 1994, 1998). 


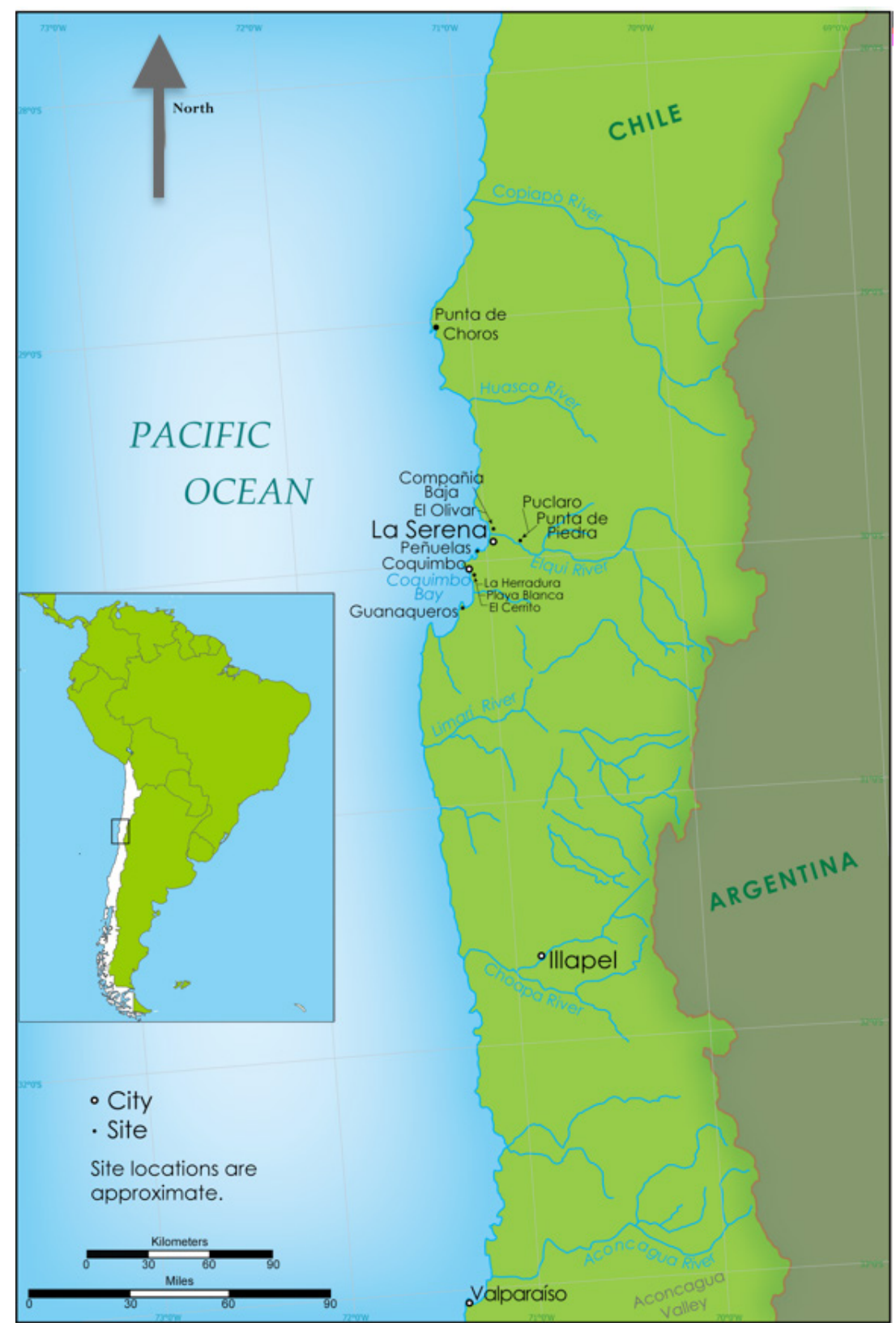

Figure 1. Semi-arid north of Chile with analyzed archaeological sites and major waterways indicated. Excavations were conducted in the early-mid 20th century prior to the use of GPS data, hence the approximate site locations.

Norte semiárido de Chile con sitios arqueológicos analizados y principales cursos de agua indicados. Las excavaciones se llevaron a cabo en la primera mitad del siglo XX antes del uso de datos de GPS, de ahi que las ubicaciones de los sitios sea aproximada. 
Using stable isotopes, Becker and colleagues (2015) expanded this understanding of diet in the semi-arid north. Comparing interior and coastal sites from the Late Archaic through Diaguita-Inka periods, they discovered that a $\mathrm{C}_{4}$ signature indicating maize consumption does not appear until the Diaguita period (Becker et al. 2015). Further, while there was an increase in marine protein consumption for Diaguita living on the coast through time, maize consumption remained stable into the Inka period (Becker et al. 2015). In general, coastal groups demonstrate a more enriched nitrogen signature, indicating a consistent exploitation of seafood, and with a continuation of a hunting and gathering (versus maize farming) subsistence is suggested during the Early Ceramic period, and there is a decrease in overall diet variability for interior groups during the Diaguita-Inka period (Becker et al. 2015). These results suggest that sedentism and agriculture did not begin until the Diaguita period, a conclusion shared by other recent contributions including Alfonso-Durruty et al. (2016).

Alfonso-Durruty and colleagues (2016) attempt to further characterize diet in the semi-arid North from the Archaic to the Late Intermediate periods, specifically examining coastal versus inland populations. The primary question being examined was when maize first appeared, given recent research suggesting the understanding about the timing of sedentary agriculture in the region may need revision (Méndez et al. 2009; Troncoso et al. 2009). Analyses of stable isotopes ${ }^{13} \mathrm{C}$ and ${ }^{15} \mathrm{~N}$ led to the conclusion that maize did not become important until the Late Intermediate period in all Diaguita groups examined, and inland Diaguita groups demonstrated enriched nitrogen values, indicating more reliance on camelids as part of the diet (Alfonso-Durruty et al. 2016). Further, comparisons between these results and others from the Americas reveal that maize consumption was not as important of a contributor to the diet in the semi-arid north as it was elsewhere (Alfonso-Durruty et al. 2016). A recent publication by Alfonso-Durruty et al. (2019) has found similar results for Northern Chile (i.e., the Atacama region) during the Late Intermediate period, indicating that the dietary trend towards reliance on marine and camelid resources with a moderated addition of maize was widespread.

In terms of pathology for these populations, researchers have found high rates of osteoporosis, osteoarthritis, periostitis, and osteomyelitis for the Archaic (Costa-Junqueira et al. 1998; Quevedo 1976), and lower caries rates for the Archaic as compared to the Diaguita (Costa-Junqueira et al. 1998; Quevedo 1976; Rosado 1994, 1998), with Rosado $(1994,1998)$ hypothesizing that the existing caries rates were assuaged by the high level of fluoride in the ocean water. Further, Rosado and Vernacchio-Wilson (2006) interpret the high bone infection rates as secondary to bacterial introduction from frequent minor cuts and scrapes from gathering shellfish in rocky and slippery tidal pools.
While subsistence and pathology have been examined separately for the semi-arid north, this is the first study for this region to contextualize stress markers in the context of subsistence strategy, namely, continued reliance on marine resources even during agricultural transition. We hypothesize that sustained marine foraging will buffer individuals from increased stress typically associated with intensifying agriculture.

\section{Materials And Methods}

The Museo Arqueológico in La Serena, Chile curates skeletal remains of Archaic and Chilean Diaguita individuals. Existing skeletal remains from the two intermediate cultures, El Molle and Las Animas, are unfortunately not well preserved. All individuals analyzed for this study came from the semi-arid north of Chile, most from the Elqui River Valley, and were excavated by museum archaeologists primarily in the early-mid $20^{\text {th }}$ century (Figure 1). Individuals drawn for this analysis came from several sites dating to different phases within each period (Table 1). A total of 95 Archaic and 75 Diaguita individuals, males and females, nonadults and adults ranging from infancy to senescence, were included (Figures 2 and 3 ). To maximize sample size, individuals from several sites were included. Sex and age estimates for adults were obtained using standard methods including Brooks and Suchey's (1990) pubic symphysis aging method, Lovejoy and colleagues' (1985) auricular surface aging method, and Brothwell's (1981) dental wear aging technique; while nonadults were aged using standards of growth and development such as tooth development and epiphyseal closure following Baker et al. (2005) and Scheuer and Black (2000).

Table 1. Sites Included.

Sitios incluidos.

\begin{tabular}{cccc}
\hline Sample & Site Name & Location & N \\
\hline \multirow{4}{*}{ Archaic } & El Cerrito & Coquimbo Bay & 67 \\
& Guanaqueros & South of Coquimbo Bay & 22 \\
& La Herradura & Coquimbo Bay & 5 \\
& Playa Blanca & Coquimbo Bay & 1 \\
\hline \multirow{4}{*}{ Diaguita } & & N=95 \\
& El Olivar & Elqui River & 12 \\
& Peñuelas & South of La Serena & 6 \\
& Peñuelas 21 & South of La Serena & 17 \\
& Peñuelas 24 & South of La Serena & 23 \\
& Illapel & North of La Serena & 4 \\
& Puclaro & Elqui River & 1 \\
& Punta de Piedra & East of La Serena & 2 \\
\hline & & & 4 \\
\hline
\end{tabular}




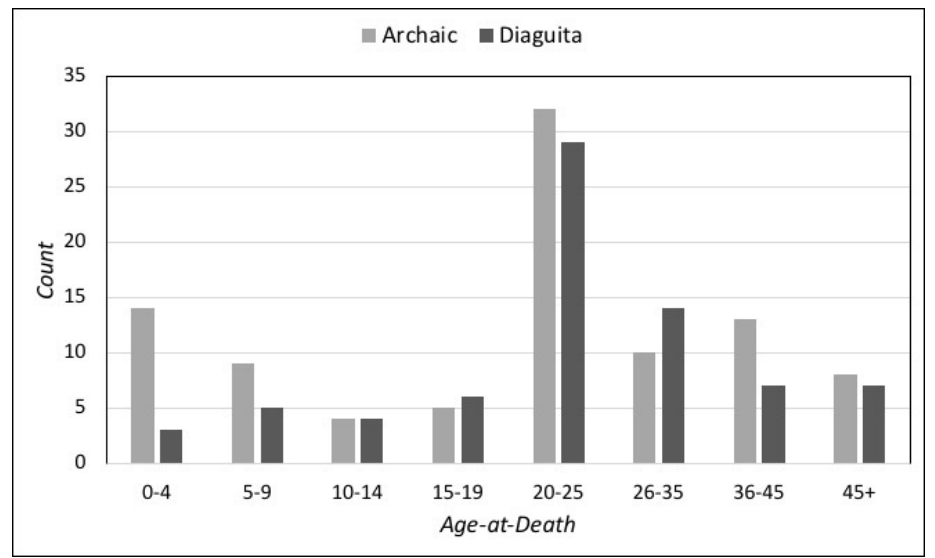

Figure 2. Age-at-death distributions, Archaic and Diaguita samples.

Distribuciones de edad al momento de la muerte, muestras arcaicas y diaguitas.

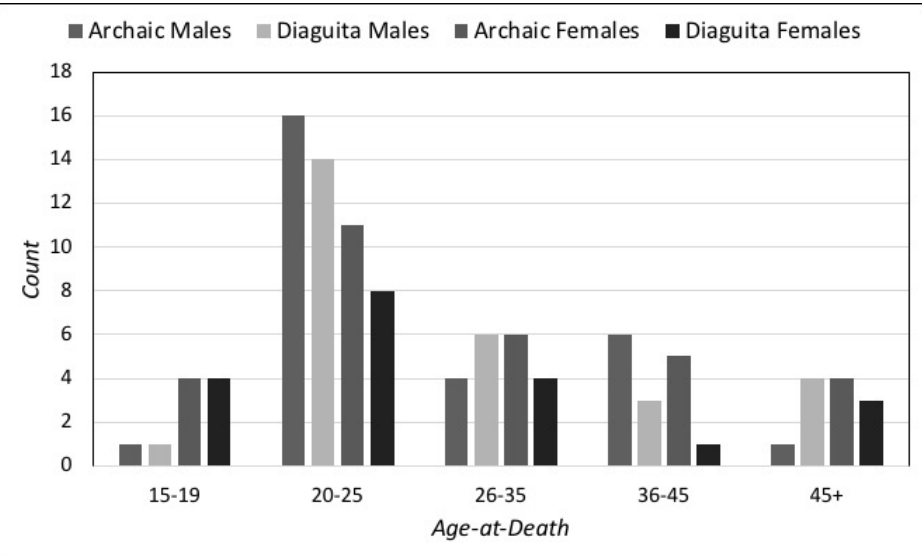

Figure 3. Sex distributions by age-at-death, Archaic and Diaguita adults. Adults with unknown sex omitted for clarity.

Distribuciones de sexo por edad al momento de la muerte de adultos Arcaicos y Diaguitas. Adultos con sexo indeterminado fueron omitidos para mayor claridad.

Variation in skeletal preservation precluded collecting data for all variables on all individuals. The total number of individuals (nonadults and adults) analyzed for each variable is shown in Table 2 .

Seven conditions are scored under the WHHI, chosen due to their frequency of appearance throughout an individual's life course: (1) linear enamel hypoplasia; (2) stature; (3) porotic hyperostosis and cribra orbitalia; (4) dental disease; (5) degenerative joint disease; (6) trauma; and (7) infection (Steckel et al. 2002a). The scores for each attribute are function values, ranging from 0 to 1 , with 0 being the severely compromised condition to 1 for the not present condition (Tables 3 and 4).

Calculating the health index for a site first involves assessment of age-specific rates of the attribute scores. These rates are ratios, with the score for each attribute given to each year of life lived divided by the number of years lived. For example, an individual who died at age 40 and had an enamel hypoplasia score of .5 would have a ratio of .5 (enamel hypoplasia score) multiplied by 40 (age-at-death) divided by 40 (number of years lived). This procedure applies to the ratios for stature, porotic hyperostosis/cribra orbitalia, and linear enamel hypoplasia. For dental disease, infection, degenerative joint disease, and trauma, an assumption is made that the condition existed for ten years before death, so instead, the ratio is constructed by multiplying the attribute score by ten (the presumed number of years the condition existed) and then divided by the age-atdeath $^{1}$. Each individual is assigned to an age category $(0-4 ; 5-14 ; 15-24 ; 25-34 ; 35-44 ; 45+)$ to account for sites with few individuals. 
Table 2. Health Index attribute scores and sample sizes.

Puntuaciones de los atributos del Índice de Salud y tamaño de las muestras.

\begin{tabular}{|c|c|c|c|c|c|}
\hline Health Index Attributes & Variables & Archaic $(\mathrm{N}=95)$ & Attribute Score & Diaguita $(\mathrm{N}=75)$ & Attribute Score \\
\hline \multirow{2}{*}{ Anemia } & Cribra Orbitalia & 53 & \multirow{2}{*}{87.3} & 45 & \multirow{2}{*}{90.2} \\
\hline & Porotic Hyperostosis & 52 & & 39 & \\
\hline Hypoplasia & Linear Enamel Hypoplasia & 39 & 95.4 & 36 & 88.3 \\
\hline \multirow{2}{*}{ Infection } & Tibial Infection & 55 & \multirow{2}{*}{51} & 33 & \multirow{2}{*}{70.3} \\
\hline & Skeletal Infection & 69 & & 51 & \\
\hline \multirow{8}{*}{ Degenerative Joint Disease } & Shoulder and Elbow DJD & 43 & \multirow{8}{*}{82.5} & 29 & \multirow{8}{*}{73.8} \\
\hline & Hip and Knee DJD & 48 & & 36 & \\
\hline & Cervical Vertebrae DJD & 30 & & 16 & \\
\hline & Thoracic Vertebrae DJD & 36 & & 17 & \\
\hline & Lumbar Vertebrae DJD & 36 & & 15 & \\
\hline & Temporomandibular DJD & 53 & & 42 & \\
\hline & Wrist DJD & 36 & & 17 & \\
\hline & Hand DJD & 33 & & 8 & \\
\hline \multirow{7}{*}{ Trauma } & Arm Trauma & 54 & \multirow{7}{*}{90.7} & 34 & \multirow{7}{*}{85.8} \\
\hline & Leg Trauma & 57 & & 45 & \\
\hline & Nasal Bones Trauma & 42 & & 39 & \\
\hline & Face Trauma & 42 & & 39 & \\
\hline & Vault Trauma & 52 & & 41 & \\
\hline & Hands Trauma & 35 & & 12 & \\
\hline & Weapon Wounds & 75 & & 57 & \\
\hline \multirow[t]{2}{*}{ Dental } & Caries & 55 & \multirow{2}{*}{87.7} & 57 & \multirow{2}{*}{81.3} \\
\hline & Abscesses & 56 & & 59 & \\
\hline
\end{tabular}

DJD=Degenerative Joint Disease

Table 3. Health Index scoring for categorical variables ${ }^{1}$

Puntaje del Índice de Salud para variables categóricas.

\begin{tabular}{|c|c|c|c|c|c|c|}
\hline \multirow{2}{*}{ Variable } & \multicolumn{6}{|c|}{ Score } \\
\hline & 0 & 1 & 2 & 3 & 4 & 5 \\
\hline Cribra Orbitalia & Not observable & Absent & Present & Gross lesions & & \\
\hline Porotic Hyperostosis & Not observable & Absent & Present & Gross lesions & & \\
\hline Auditory Exostosis & Not observable & Absent & Present & & & \\
\hline Tibial Infection & Not observable & Absent & Slight & Moderate & Severe & \\
\hline Skeletal Infection & No infection & Present & Systemic & & & \\
\hline Shoulder and Elbow DJD & Not observable & No DJD & Initial & Severe & Immobilization & Systemic \\
\hline Hip and Knee DJD & Not observable & No DJD & Initial & Severe & Immobilization & Systemic \\
\hline Cervical Vertebrae DJD & Not observable & No DJD & Initial & Extensive & Body Fusion & \\
\hline Thoracic Vertebrae DJD & Not observable & No DJD & Initial & Extensive & Body Fusion & \\
\hline Lumbar Vertebrae DJD & Not observable & No DJD & Initial & Extensive & Body Fusion & \\
\hline Temporomandibular DJD & Not observable & No DJD & Present & & & \\
\hline Wrist DJD & Not observable & No DJD & Present & & & \\
\hline Hand DJD & Not observable & No DJD & Present & & & \\
\hline Arm Trauma & Not observable & No Fracture & Healed & Healed; malaligned & Healed with joint fusion & Healed, alignment unknown \\
\hline Leg Trauma & Not observable & No Fracture & Healed & Healed; locomotion loss & Healed; major locomotion loss & Healed, alignment unknown \\
\hline Nasal Bones Trauma & Not observable & No Fracture & Healed & & & \\
\hline Face Trauma & Not observable & No Fracture & Healed & & & \\
\hline Vault Trauma & Not observable & No Fracture & Healed & & & \\
\hline Hands Trauma & Not observable & No Fracture & Healed & & & \\
\hline Weapon Wounds & & Absent & Present & & & \\
\hline
\end{tabular}

DJD=Degenerative Joint Disease.

${ }^{1}$ Stature is also evaluated by the health index. Maximum length of the femur is taken, and a score of 100 is given if the individual attained modern femur standards for their age based on Maresh (1955). Those individuals below three standard deviations are given a score of 0. 
Table 4. Health Index scoring for enamel hypoplasia and dental disease.

Puntaje del Índice de Salud para hipoplasia del esmalte y enfermedad dental.

\begin{tabular}{|c|c|c|c|c|}
\hline \multirow[t]{2}{*}{ Condition } & \multicolumn{4}{|c|}{ Score } \\
\hline & 0 & 1 & 2 & 3 \\
\hline $\begin{array}{l}\text { Linear Enamel } \\
\text { Hypoplasia }\end{array}$ & Not observable & No hypoplasia & One hypoplasia & Two or more hypoplasias \\
\hline Caries & & $\begin{array}{l}\text { Total } N \text { of permanent } \\
\text { teeth observed }\end{array}$ & $\begin{array}{l}\text { Total } \mathrm{N} \text { of permanent teeth } \\
\text { lost antemortem }\end{array}$ & $\begin{array}{c}\text { Total N of teeth with lesions } \\
\text { or fillings }\end{array}$ \\
\hline Abscesses & & $\begin{array}{l}\text { Total } \mathrm{N} \text { of sockets } \\
\text { examined }\end{array}$ & Total $\mathrm{N}$ of abscesses & \\
\hline
\end{tabular}

A Model West Level 4 life table ${ }^{2}$ is used as the reference population to provide a weighted age-atdeath, to which the ratios within each age category are multiplied to provide average scores for each attribute. Each individual's ratio, or age-specific rates for each attribute, is then summed within each age category, and divided by life expectancy at birth in the reference population (26.4 years). The result is the attribute score as a percentage of the maximum attainable life expectancy (known as quality adjusted life years) for the tested population. The scores for each of the seven attribute values are then averaged, producing a final score. The closer this value is to 100 , the less stressed the population was, because the value indicates fewer markers of stress.

To determine if any of the variables increased with age-at-death, binary logistic regression was calculated using the youngest adult age category as a reference (15-19). These models were evaluated using the Hosmer-Lemeshow goodness of fit test.

\section{Results}

Health index values were the same for both the Archaic and Diaguita cultures (70.8\%). However, there were some differences between the attribute values when compared between cultures (Table 5). The Diaguita had higher values for stature (5.7 vs. 1.1), and a lower frequency of lesions such as porotic hyperostosis/cribra orbitalia (90.2 vs. 87.3) and infections (70.3 vs. 51). Conversely, the Archaic had higher scores (and thus a lower frequency) for linear enamel hypoplasia ( $95.4 \mathrm{vs}$. 88.3 ), dental disease (87.7 vs. 81.3), degenerative joint disease (82.5 vs. 73.8 ) and trauma (90.7 vs. 85.8).

A binary logistic regression was used to assess the odds of age-at-death predicting any of the health index variables. The results of these analyses were insignificant. In addition, the Hosmer-Lemeshow goodness of fit test demonstrated that models were a good fit for the data, despite small sample size.

\section{Discussion}

As measured by the Western Hemisphere Health Index, the two prehistoric Chilean samples analyzed here had equivalent values of stress. Of the original 65 sites included in Steckel and Rose (2002), coastal sites $(n=15)$ typically demonstrated health index values above 80, suggesting low physiological stress (Table 6). Only one site in the original study, located in coastal California, ranked below this mark at 69.8 (Steckel et al. 2002b). The results here place the Archaic and Diaguita groups slightly higher than one of the coastal California samples (1359 years BP) and one of the coastal northern Chilean samples (6015 years BP). The comparatively low value for the Chileans overall (70.8) as compared to other coastal sites in the Western Hemisphere is brought down by the low stature values, which may be confounded by genetic variation. Further, perusal of Table 6 reveals that most of the coastal sites from Steckel et al. (2002b) are in North America, with the majority being different time periods in California or South Carolina. The values from the Archaic and Diaguita place them in tandem with the included South American coastal sites $(n=3)$ with the South Coast of Ecuador (1760 years BP) having the highest South American value (75.1)

The relationship between age-at-death and presence of pathology between samples was found to be insignificant. If age is not affecting pathology presence, this suggests that the factors leading to pathology

Table 5. Health Index results.

Resultados del Índice de Salud.

\begin{tabular}{cccccccccc}
\hline Culture & $\begin{array}{c}\text { Quality-adjusted } \\
\text { life years }\end{array}$ & $\begin{array}{c}\% \text { maximum } \\
\text { attainable }\end{array}$ & Stature & Hypoplasia & Anemia & Dental & Infection & DJD & Trauma \\
\hline Archaic & 18.68 & 70.8 & 1.1 & 95.4 & 87.3 & 87.7 & 51 & 82.5 & 90.7 \\
Diaguita & 18.67 & 70.8 & 5.7 & 88.3 & 90.2 & 81.3 & 70.3 & 73.8 & 85.8 \\
\hline
\end{tabular}


Table 6. Comparison of Archaic and Diaguita health index results to other coastal sites.

Comparación de los resultados del índice de salud Arcaico y Diaguita con otros sitios costeros.

\begin{tabular}{lcc}
\hline \multicolumn{1}{c}{ Site and Date } & $\begin{array}{c}\text { Quality-adjusted } \\
\text { life years }\end{array}$ & $\begin{array}{c}\% \text { maximum } \\
\text { attainable }\end{array}$ \\
\hline *Coastal Brazil, 1200 & 24.22 & 91.8 \\
\hline Coastal South Carolina, 1350 & 23.54 & 89.2 \\
\hline Coastal South Carolina, 0325 & 22.10 & 83.8 \\
\hline Coastal Southern California, 1075 & 21.75 & 82.4 \\
\hline Coastal South Carolina, 0600 & 21.34 & 80.9 \\
\hline Coastal South Carolina, 1350 & 21.19 & 80.3 \\
\hline Coastal Southern California, 5250 & 21.10 & 80.0 \\
\hline Coastal Southern California, 3834 & 20.85 & 79.0 \\
\hline Coastal Southern California, 1625 & 20.14 & 76.3 \\
\hline Coastal Southern California, 0434 & 19.96 & 75.7 \\
\hline South Coast, Ecuador, 1760 & 19.81 & 75.1 \\
\hline Coastal South Carolina, 0325 & 19.41 & 73.6 \\
\hline North Coast, Ecuador, 2050 & 19.18 & 72.7 \\
\hline Archaic (this study) & 18.68 & 70.8 \\
\hline Diaguita (this study) & 18.67 & 70.8 \\
\hline Coastal Southern California, 1359 & 18.41 & 69.8 \\
\hline Coastal Chile, 6015 & 18.09 & 68.6 \\
\hline D &
\end{tabular}

Data reproduced from Steckel and Rose (2002b). Maximum attainable quality-adjusted life years is 26.38 . Dates are given in years before present (i.e., before $1950 \mathrm{AD}$ ). Sites in South America are presented in italics.

"Refer to the text for a discussion of the results from Coastal Brazil.

manifestation are the same for everyone, regardless of age. This is particularly likely for the Archaic sample which had a higher level of infection than the Diaguita. As introduced earlier, it is plausible that one consequence of ocean subsistence is infection, as even children could participate in certain food-procuring activities, such as gathering shellfish or mollusks from shallow tidal pools (DiGangi 2008). This would serve to increase the likelihood of obtaining easily-infected minor scrapes and cuts from the rocky and slippery environment (Rosado and Vernacchio-Wilson 2006).

\section{Coastal Habitation and Stress}

The results obtained here appear to fit a model that involves decreased physiological stress for groups subsisting on marine resources. This result is not a novel one, as several studies have demonstrated low frequencies of skeletal stress markers with coastal habitation and subsistence in prehistory worldwide (Benfer 1990 for Peru; Tayles et al. 2000 for Southeast Asia; Alfonso et al. 2007 and Watson et al. 2010, 2013 for northern Chile; Gómez and Novellino 2011 for Argentina; and Temple 2010 for Japan).

However, it is important to note that the relationship between marine subsistence and low physiological stress is not a hard and fast rule. Walker (1986) and Lambert (1993) found an increase in porotic hyperostosis and periostitis for prehistoric coastal California, interpreted by these authors as a result of nutrient deficiency due to overreliance on fish, or water contamination as a result of increased population density. Similarly, for native California, Walker and Thornton (2002) found that there were many fluctuations in stress markers through time, which they partially attribute to periodic changes in the marine environment which affected resource biomass. Larsen and colleagues (2002) found that caries rates increased with agriculture for the coastal Georgia Bight; and Pechenkina et al. (2007) found a general increase in caries through time, as well as porotic hyperostosis and cribra orbitalia. In their re-evaluation of Neves and Wesolowski's (2002) assessment of health in the southern Brazilian shellmound region, Hubbe and colleagues (2017) suggested that coastal groups in this region were likely affected by high levels of infectious disease, associated with shorter stature and a higher prevalence of porotic hyperostosis and cribra orbitalia.

For those coastal populations that had adopted maize subsistence and were not protected from increasing stress markers, it is likely cultural factors that worked against, and even negated, any nutritional benefits accrued with coastal subsistence. As highlighted elsewhere, such factors may be related to increased population density, such as water contamination, which may have been more significant than could be buffered culturally. Therefore, it appears that a simple pattern of coastal living equaling an improvement in well-being or quality of life does not exist. Rather, other features of the physical environment (i.e., location of water sources, level of contamination) and sociopolitical environment (i.e., population density, relative access to resources) are likely major contributors to health patterns in coastal populations. Further, it is important to note that each population is a distinct entity, differentially affected by environmental, social, and biological factors. Factors that may be detrimental to one population (such as an increased population size leading to increased communicable disease due to increased contact with waste) may not be as consequential in another population, where perhaps a better social system exists for the disposal of waste.

\section{Coastal Living Advantages and Exceptions}

Due in large part to food resource availability, coastal living overall appears to confer an advantage to both food collectors and maize agriculturalists, but there are exceptions, discussed above. Factors such as water contamination and overreliance on one specific food are important to understand but have yet to be fully teased out. However, the current picture suggests that when coastal populations are compared en masse to 
terrestrial ones, coastal populations seem to fare better in a variety of different measurements, e.g., caries rates, stature, cribra orbitalia, and linear enamel hypoplasia (Alfonso et al. 2007; Benfer 1990; DiGangi 2008; Watson et al. 2010). This emphasizes the role that coastal environments, in concert with cultural adaptations, play in buffering physiological stress.

For the populations examined here from the semi-arid north of Chile, it appears that the oceanbased diet is a major buffer, and in fact, other scholars of prehistoric Chile have supported this perspective (Arriaza et al. 2001; Muñoz 2004). Human occupation in this region spans back hundreds of generations, and such expansive culture history involving the ocean as a centerpiece to daily life indicates that building and passing on knowledge of how to exploit its resources was of paramount importance. Cultural adaptations to this environment and its exploitation may have been specifically protective as well, and are yet to be fully elucidated.

\section{Methodological Perspectives and Limitations}

Recent literature has highlighted the difficulty in attempting to assess "health" from stress indicators within the skeleton (e.g., DeWitte and Stojanowski 2015; Temple and Goodman 2014). Among other challenges, Wood and colleagues (1992) highlight the importance of considering individual frailty (susceptibility to disease and death) in relation to skeletal lesions. As previously mentioned, individuals with inactive or healing lesions may in fact represent "healthier" (lower frailty) individuals than those who are free of lesions. Individuals without lesions may in fact represent those whose frailty made them more vulnerable to acute stress and disease, conditions that would not necessarily show up on bone due to their rapid onset.

Additionally, we acknowledge that while nutrition and pathology are inextricably linked, this relationship is complex and variable. Subsistence, physical environment (including parental and grandparental environment), early-life experience, behavior, and sociopolitical organization (including status) are just a few of the variables which interact in human health (see Gowland 2015). While this study demonstrates no change in health status between the Archaic and Diaguita samples as per health index methodology, it is possible that the interaction of the aforementioned variables are more complex than can be accounted for using the original WHHI framework.

In their recently released Backbone of Europe text, Steckel and colleagues (2019) build upon the same seven variables outlined in the original WHHI, due in part to their ability to capture multiple dimensions of human well-being. However, the editors point out that several areas of the methodology have been adjusted to extend and deepen previous work in the Western Hemisphere. In particular, the recently revised method includes more joints in their analysis of osteoarthritis, expands the regions examined for trauma, provides more options for scoring severity in several categories, and includes room for discussion of metabolic and infectious disease (Steckel et al. 2019). For the purposes of this study, the original variables and scoring index for WHHI was used to allow for comparisons within the Americas. However, we acknowledge that many of the limitations of the original health index would be remedied with the changes made for the European Health History Project.

Hubbe and colleagues (2017) note that despite the outlined methodological limitations of the original WHHI, it still provides valuable population sample information that is easily comparable across regions. While bioarchaeological literature is increasingly focused on within population and individual level analyses, we believe the examination of comparative trends in well-being remains warranted, because it allows a higher-level understanding of local, regional, and pan-regional trends. Comparative studies are invaluable for their ability to examine each population within its unique context, followed by a comparison of any observed similarities and differences between groups. Such studies may help elucidate not only what the factors were that led to differences, but the nuances of how a particular variable may have affected separate groups differentially given the unique interaction of variables in each context.

\section{Conclusion}

For these prehistoric populations from the semiarid north of Chile, the addition of agriculture to exploitation of marine resources did not significantly alter most measured stress markers. It is possible these results are due to the relatively smaller importance of maize in the diet as demonstrated by stable isotope analysis (Alfonso-Durruty et al. 2016; Becker et al. 2015). Further, it is clear that the seeming correlation of fewer skeletal stress markers to marine subsistence is not universally demonstrated for all coastal groups.

Simple one-to-one explanations about a marine diet leading to better health ignore both nuances of local environment as well as cultural adaptations. Such environmental nuances include pathogen presence, location of fresh water sources to population centers, and rainfall; and these along with cultural adaptations such as waste disposal and types of agricultural activities will influence different methods of disease transmission (Sattenspiel 2000). The diverse subsistence strategy in addition to the diversity of resources available in a 
coastal, marine environment were probably contributors. Questions regarding the nature of the socio-political environment in each population and the role it played in behavior and adaptation, insofar as this context related to experiential and functional health/quality of life, is an avenue that deserves future exploration.

For the Diaguita, it appears that a confluence of cultural adaptations, diet, and particularities of the environment provided buffering from the types of physiological stress seen in many other agricultural populations. For prehistoric populations from Argentina, Gómez and Novellino (2011) argue that a mixed marine and terrestrial diet was preferable to reliance on one source alone in terms of health outcomes. The results here support this assessment. Further, a modern study of farmers and foragers from Madagascar demonstrated that a combination of foraging and farming is superior to either method alone, as it diminishes the risks inherent with farming (Tucker et al. 2010). If farming risks are assuaged, a logical conclusion that follows is that such a combination of subsistence strategies would therefore also contribute to lessened physiological stress. This situation was likely the case for prehistoric Chile, and future research should explore how cultural adaptations contributed to physiological stress remaining relatively stable after the addition of agriculture to the subsistence strategy of this region.

Acknowledgments: The Museo Arqueológico in La Serena, Chile curates the remains included in this study. We thank Dr. Gabriel Cobo, former director; as well as the entire museum staff. Dr. Gonzalo Ampuero generously provided key resources and was a useful source of information during data collection. EAD is grateful to Dr. Maria Rosado for the many opportunities she has provided, including introducing her to the skeletal collections at the museum as well as for serving as her initial liaison with museum colleagues. Dr. Gary James was a useful source of statistical consulting, and Sarah Cunningham assisted with aspects of the literature review. Adriana Otero and Ruth Mendez assisted with Spanish translation. We thank the two anonymous reviewers for their valuable suggestions. An award to EAD from The W.K. McClure Fund of the University of Tennessee, Knoxville funded part of the travel related to data collection.

\section{References Cited}

Alfonso, M., VG, Standen, and M.V. Castro 2007. The adoption of agriculture among Northern Chile populations in the Azapa Valley, 9000-1000 BP. In Ancient Health: Skeletal Indicators of Agricultural and Economic Intensification, edited by M.N. Cohen, and G.M. Crane-Kramer, pp. 113-129. University Press of Florida, Gainesville.

Alfonso-Durruty, M., A. Troncoso, P. Larach, C. Becker, and N. Misarti 2016. Maize (Zea mays) consumption in the southern Andes (30-31 S. Lat): Stable isotope evidence (2000 BCE-1540 CE). American Journal of Physical Anthropology 164 (1):148-162.

Alfonso-Durruty, M., E. Gayo, V. Standen, V. Castro, C. Latorre, C.M. Santoro, and D. Valenzuela 2019. Dietary diversity in the Atacama desert during the Late Intermediate period of Northern Chile. Quaternary Science Reviews 214:54-67.

Ampuero, B.G. 1986. Antiguas Culturas del Norte Chico. Museo Arqueológico de La Serena, La Serena.

Ampuero, B.G. 1989. La Cultura Diaguita chilena. In Culturas de Chile Prehistoria desde sus Orígenes hasta los Albores de la Conquista, edited by J. Hidalgo, V. Schiappacasse, H. Niemeyer, C. Aldunate del Solar, and I. Solimano, pp. 277288. Editorial Andres Bello, Santiago.

Ampuero, B.G. 1994. Cultura Diaguita. Serie Patrimonio Cultural Chileno, Colección Culturas Aborígenes. División de Extensión Cultural del Ministerio de Educación, Santiago.

Ampuero, B.G. 2010. Prehistoria de la Región de Coquimbo. Chile. Andros Impresores, Santiago.

Arriaza, B.T., V.G. Standen, E. Belmonte, F. Neils, and E. Rosello 2001. The peopling of the Arica coast during the preceramic: A preliminary view. Chungara Revista de Anthropologia Chilena 33 (1):31-36

Baker, B.J., T.L. Dupras, M. Tocheri, and S. Wheeler 2005. The Osteology of Infants and Children. Texas A\&M University Press, College Station

Becker, C., M. Alfonso, N. Misarti, A. Troncoso, and P. Larach 2015. Isotopos estables y dieta en poblaciones prehispánicas del Norte Semiárido (30-32 Lat. S): Una primera aproximación desde el Arcaico Tardío hasta el periodo Incaico. Boletín del Museo Nacional de Historia Natural 64:107-119.

Benfer R. 1990. The preceramic period site of Paloma, Peru: Bioindications of improving adaptation to sedentism. Latin American Antiquity 1 (4):284-318.

Bird, J.B. 1943. Excavations in Northern Chile. American Museum of Natural History, New York.

Bogucki, P. 1999. The Origins of Human Society. Blackwell, Malden.

Brooks, S., and J.M. Suchey 1990. Skeletal age determination based on the os pubis: a comparison of the Acsadi-Nemeskeri and Suchey-Brooks methods. Human Evolution 5 (3):227-238.

Brothwell, D.R. 1981. Digging up Bones: The Excavation, Treatment, and Study of Human Skeletal Remains. 3rd ed. Cornell University Press, Ithaca.

Buikstra, J.E. 1992. Diet and disease in late prehistory. In Disease and Demography in the Americas: Changing Patterns Before and After 1492, edited by J. Verano, and D.H. Ubelaker, pp. 87-102. Smithsonian Institution Press, Washington, D.C.

Castillo, G.G. 1989. Agricultultores y pescadores del Norte Chico: El Complejo Las Ánimas (800 a 1.200 d.C.). In Culturas 
de Chile Prehistoria desde sus Orígenes hasta los Albores de la Conquista, editado por J. Hidalgo, V. Schiappacasse, H. Niemeyer, C. Aldunate del Solar, and I. Solimano, pp. 265276. Editorial Andrés Bello, Santiago.

Childe, V. 1951. Man Makes Himself. Mentor, New York.

Coale, A., and P. Demeny 1983. Regional Model Life Tables and Stable Populations. Academic Press, New York.

Cohen, M.N. 1977. The Food Crisis in Prehistory: Overpopulation and the Origins of Agriculture. Yale University Press, New Haven.

Cohen, M.N. 1989. Health and the Rise of Civilization. Yale University Press, New Haven.

Cohen, M.N., and G.J. Armelagos (ed.) 1984. Paleopathology and the Origins of Agriculture. Academic Press, New York.

Cohen, M.N., and G.M. Crane-Kramer (ed.) 2007. Ancient Health: Skeletal Indicators of Agricultural and Economic Intensification. University Press of Florida, Gainesville.

Costa-Junqueira, M., S. Quevedo, J.A. Cocilovo, and A Llagostera 1998. El hombre arcaico costero: su biodiversidad y bioadaptación. Unpublished manuscript on file at the Museo Arqueológico de La Serena, La Serena.

David, L.A., C.F. Maurice, R.N. Carmody, D.B. Gootenberg, J.F. Button, B.E. Wolfe, A.V. Ling, A.S. Devlin, Y. Varma, M.A Fischbach, S.B. Biddinger, R.J. Dutton, and P.J. Turnbaugh 2014. Diet rapidly and reproducibly alters the human gut microbiome. Nature 505 (7484):559-563.

DiGangi, E.A. 2008. Application of the Western Hemisphere Health Index to Prehistoric Populations from Tennessee and the Semi-arid North of Chile: A Comparative Bioarchaeological Study of the Implications of Subsistence Choice. Unpublished $\mathrm{PhD}$ Dissertation. The University of Tennessee, Knoxville.

DeWitte, S.N., and C.M. Stojanowski 2015. The osteological paradox 20 years later: Past perspectives, future directions. Journal of Archaeological Research 23 (4):397-450.

Gómez Otero, J., and P. Novellino 2011. Diet, nutritional status and oral health in hunter-gatherers from the central-northern coast of Patagonia and the Chubut River Lower Valley, Argentina. International Journal of Osteoarchaeology 21:643-659.

Goodman, A.H. and D.L. Martin 2002. Reconstructing health profiles from skeletal remains. In The Backbone of History: Health and Nutrition in the Western Hemisphere, edited by J.C. Rose and R.H. Steckel, pp. 11-60. Cambridge University Press, Cambridge.

Goodman, A.H., D.L. Martin, G.J. Armelagos, and G. Clark 1984 Indications of stress from bones and teeth. In Paleopathology at the Origins of Agriculture, edited by M.N. Cohen, and G.J. Armelagos, pp. 13-49. Academic Press, New York.

Gowland, R.L. 2015. Entangled lives: Implications of the developmental origins of health and disease hypothesis for bioarchaeology and the life course. American Journal of Physical Anthropology 158:530-540.

Grosjean, M., C.M. Santoro, L. Thompson, L. Núnez, and V.G. Standen 2007. Mid-Holocene climate and culture change in the South Central Andes. In Climate Change and Cultural Dynamics: A Global Perspective on Mid-Holocene Transitions, edited by D.A. Anderson, K. Maasch, and D Sandweiss, pp. 51-115. Elsevier, New York.
Hubbe, M., M.K. Green, C.M. Cheverko, and W.A. Neves 2017. Brief communication: A re-evaluation of the health index of southern Brazilian shellmound populations. American Journal of Physical Anthropology 165:353-362.

Kuzmanic, I., and G.G. Castillo 1986. Estadio Arcaico en la costa del norte semiárido de Chile. Chungara Revista de Anthropologia Chilena 16-17:89-94.

Lambert, P.M. 1993. Health in prehistoric populations of the Santa Barbara Channel Islands. American Antiquity 58 (3):509-522

Larsen, C.S. 1995. Biological changes in human populations with agriculture. Annual Review of Anthropology 24:185-213.

Larsen, C.S, A. Crosby, M. Griffin, D.L. Hutchinson, C.B. Ruff, K. Russell, M. Schoeninger, L. Sering, S. Simpson, J. Takács, and M.F. Teaford 2002. A biohistory of health and behavior in the Georgia Bight. In The Backbone of History: Health and Nutrition in the Western Hemisphere, edited by R.H. Steckel, and J.C. Rose, pp. 406-439. Cambridge University Press, New York.

Larsen, C.S. 2015. Bioarchaeology: Interpreting Behavior from the Human Skeleton. $2^{\text {nd }}$ edition. Cambridge University Press, Cambridge.

Lee, R., and I. DeVore 1976. Kalahari Hunter Gatherers - Studies of the Kung! San and Their Neighbors. Harvard University Press, Cambridge.

López M., P., I. Cartajena F., B. Santander, D. Villalón, A. Sáez, and B. Rivera 2016. Procesamiento de guanacos durante el Arcaico Tardio del Norte Semiarido de Chile: un acercamiento zooarqueologico y espacial intrasitio. Chungara Revista de Anthropologia Chilena 48 (2):243-258.

Lovejoy, C.O, R.S. Meindl, T.R. Pryzbeck, and R.P. Mensforth 1985. Chronological metamorphosis of the auricular surface of the ilium: a new method for the determination of adult skeletal age at death. American Journal of Physical Anthropology 68 (1):15-28.

Maldonado, A., M.E. de Porras, A. Zamora, M. Rivadeneira, and A.M. Abarzúa 2016. El escenario geográfico y paleoambiental de Chile. In Prehistoria de Chile: desde sus Primeros Habitantes hasta los Incas, edited by F. Falabella, M. Uribe, L. Sanhueza, C. Aldunate, and J Hidalgo, pp. 23-70. Editorial Universitaria, Santiago.

Maresh, M.M. 1955. Linear growth of long bones of extremities from infancy through adolescence. A.M.A. American Journal of Diseases of Children 89 (6):725-742.

Marklein, K.E, R.E. Leahy, and D.E. Crews 2016. In sickness and in death: Assessing frailty in human skeletal remains. American Journal of Physical Anthropology 161 (2):208-225.

McIlvaine, B.K., and L.J. Reitsema 2013. A look at the literature: Recent developments and long-term trends in the interpretation of skeletal stress markers and ancient health. American Journal of Physical Anthropology 150 (?):194-195.

Méndez, C., S. Grasser, D. Jackson, A. Troncoso, and B. Santander 2016. Ocupaciones humanas del Holoceno Medio en Los Andes del Norte Semiárido de Chile (31 Degrees S, Combarbala): función del sitio e implicancias para el uso regional del espacio. Chungara Revista de Antropología Chilena 48 (2):225-241.

Méndez, C., A. Troncoso, D. Jackson, and D. Pavlovic 2009 Movilidad y uso del espacio entre cazadores-recolectores tardios en espacios cordilleranos del Norte Semiarido de Chile. Intersecciones en Antropología 10:311-324. 
Moseley, M.E. 1999. Andean coastal adaptations: uniformitarianism and multilinear evolution. In Pacific Latin America in Prehistory, edited by M. Blake, pp. 171-180. Washington State University Press, Pullman.

Muñoz Ovalle, I. 2004. El periodo Formativo en los valles del norte de Chile y sur de Peru: Nuevas evidencias y comentarios. Chungara Revista de Antropologia Chilena Especial:213-225.

Neves, W.A., and V. Wesolowski 2002. Economy, nutrition, and disease in prehistoric coastal Brazil: A case study from the state of Santa Catarina. In The Backbone of History: Health and Nutrition in the Western Hemisphere, edited by R.H. Steckel, and J.C. Rose, pp. 376-402. Cambridge University Press, New York.

Niemeyer F., H., G.G. Castillo, and G.M. Cervellino 1989. Los primeros ceramistas del Norte Chico: Complejo El Molle (0 a 800 d.C.). In Culturas de Chile Prehistoria Desde sus Origenes hasta los Albores de la Conquista, edited by J. Hidalgo, V. Schiappacasse, H. Niemeyer, C. Aldunate del Solar, and I. Solimano, pp. 227-264. Editorial Andres Bello, Santiago.

Niemeyer F., H., and P. Cereceda 1983. Ríos en torrente de régimen mixto en la zona semiárida de Chile. Geografía de Chile, pp. 85-135. Instituto Geografico Militar Hidrografia, Santiago.

Norr, L.C. 1991. Nutritional Consequences of Prehistoric Subsistence Strategies in Lower Central America. Unpublished $\mathrm{PhD}$ dissertation, Department of Anthropology, University of Illinois-Urbana-Champaign.

Pechenkina, E.A., J.A. Vradenberg, R. Benfer, and J. Farnum 2007. Skeletal biology of the central Peruvian coast: Consequences of changing population density and progressive dependence on maize agriculture. In Ancient Health: Skeletal Indicators of Agricultural and Economic Intensification, edited by M.N. Cohen, and G.M. CraneKramer, pp. 92-112. The University Press of Florida, Gainesville.

Pinhasi, R., and J.T. Stock (ed.) 2011. Human Bioarchaeology of the Transition to Agriculture. Wiley-Blackwell, Oxford.

Quevedo, S. 1976. Estudio de un Cementerio Prehistórico: Exploración de sus Potenciales Demográficas y Socioculturales. Universidad de Chile, Santiago.

Quevedo, S., J.A. Cocilovo, and F. Rothhammer 1982. Relaciones y afinidades biológicas entre las poblaciones del norte semiárido (Chile). Actas del IX Congreso Nacional de Arqueologia, pp. 248-268, La Serena.

Reitsema, L.J., and B.K. McIlvaine 2014. Reconciling "stress" and "health" in physical anthropology: What can bioarchaeologists learn from the other subdisciplines? American Journal of Physical Anthropology 155:181-185.

Rosado, M.A. 1994. Health and Diet of Two Prehistoric Populations from Chile's Semiarid North $\mathrm{PhD}$ Thesis, Department of Anthropology, Rutgers University, New Brunswick, New Jersey.

Rosado, M.A. 1998. Dental health and diet of two prehistoric populations from Chile's semiarid north. Dental Anthropology 13 (1):2-9.

Rosado, M.A., and J. Vernacchio-Wilson 2006. Paleopathology and osteobiography of the people of Penuelas, Chile's semiarid north. Mem Inst Oswaldo Cruz, Rio de Janeiro 101 (Suppl. II):85-95.

Sattenspiel, L. 2000. Tropical environments, human activities, and the transmission of infectious diseases. Yearbook of Physical Anthropology 43:3-31.
Scheuer, L., and S. Black 2000. Developmental Juvenile Osteology. Academic Press, London.

Scrimshaw, N. 2003. Historical concepts of interactions, synergism, and antagonism between nutrition and infection. The Journal of Nutrition 133:316S-321S

Scrimshaw, N., C. Taylor, and J. Gordon 1968. Interactions of Nutrition and Infection. World Health Organization, Série de monographies. Geneva.

Steckel, R.H., C.S. Larsen, C.A. Roberts and J. Baten (eds.) 2019. The Backbone of Europe: Health, Diet, Work, and Violence over Two Millennia. Cambridge University Press, Cambridge.

Steckel, R.H., and J.C. Rose (eds.) 2002. The Backbone of History: Health and Nutrition in the Western Hemisphere. Cambridge University Press, Cambridge.

Steckel, R.H., J.C. Rose, C.S. Larsen, and P.L. Walker 2002a. Skeletal health in the Western Hemisphere from 4000 B.C. to the present. Evolutionary Anthropology 11:142-155.

Steckel, R.H., P.W. Sciulli, and J.C. Rose. 2002b. A health index from skeletal remains. In The Backbone of History: Health and Nutrition in the Western Hemisphere edited by R.H. Steckel, and J.C. Rose , pp. 61-93. Cambridge University Press, Cambridge.

Tayles N., K. Domett, and K. Nelson 2000. Agriculture and dental caries? The case of rice in prehistoric southeast Asia. World Archaeology 32 (1):68-83.

Temple, D.H. 2010. Patterns of systemic stress during the agricultural transition in prehistoric Japan. American Journal of Physical Anthropology 142:112-124.

Temple, D.H., and A.H. Goodman 2014. Bioarchaeology has a "health" problem: Conceptualizing "stress" and "health" in bioarchaeological research. American Journal of Physical Anthropology 155:186-191.

Troncoso A. 1998 (Impreso 1999). La cultura Diaguita en el valle de Illapel: una perspectiva exploratoria. Chungara Revista de Antropología Chilena 30 (2):125-142.

Troncoso, A., C. Becker, D. Pavlovic, P. Gonzalez, J. Rodriquez, and C. Solervicens 2009. El sitio LV099-B Fundo Agua Amarilla y la ocupacion del periodo Incaico en la costa de la Provincia del Choapa, IV region. Chungara Revista de Antropología Chilena 41 (2):241-259.

Troncoso. A., G. Cantarutti, and P. Gonzalez 2016b. Desarrollo historico y variabilidad espacial de las comunidades alfareras del Norte Semiarido. In Prehistoria de Chile: Desde Sus Primeros Habitantes Hasta Los Incas, edited by F. Falabella, M. Uribe, L. Sanhueza, C. Aldunate, and J. Hidalgo, pp. 319-364. Editorial Universitaria, SA. Santiago.

Troncoso. A., F. Vergara, D. Pavlovic, P. Gonzalez, M. Pino, P. Larach, A. Escudero, N. La Mura, F. Moya, I. Pérez, R. Gutiérrez, D. Pascual, C. Belmar, M. Basile, P. López, C. Davila, M.J. Vasquez, and P. Urzua 2016a. Dinámica espacial y temporal de las ocupaciones prehispánicas en la cuenca hidrográfica del Río Limarí (30 Lat. S). Chungara Revista de Antropologia Chilena 48 (2):199-224.

Tucker, B., M. Tsimitamby, F. Humber, S. Benbow, and T. Iida. 2010 Foraging for development: A comparison of food insecurity, production, and risk among farmers, forest foragers, and marine foragers in southwestern Madagascar. Human Organization 69 (4):375-386. 
Walker, P.L. 1986. Porotic hyperostosis in a marine-dependent California Indian population. American Journal of Physical Anthropology 69:345-354.

Walker, P.L., and R. Thornton 2002. Health, nutrition, and demographic change in native Calfornia. In The Backbone of History: Health and Nutrition in the Western Hemisphere, edited by R.H. Steckel, and J.C. Rose, pp. 506-523. Cambridge University Press, New York.

Watson, J.T., B. Arriaza, V. Standen, and I. Muñoz Ovalle 2013. Tooth wear related to marine foraging, agro-pastoralism, and the formative transition on the northern Chilean coast. International Journal of Osteoarchaeology 23:287-302.

Watson, J.T., I. Muñoz Ovalle, and B.T. Arriaza 2010. Formative adaptations, diet, and oral health in the Azapa Valley of Northwest Chile. Latin American Antiquity 21 (4):423-439.

Wood, J.W., G.R. Milner, H.C. Harpending, and K.M. Weiss 1992. The osteological paradox: problems of inferring prehistoric health from skeletal samples. Current Anthropology 33:343-358.

\section{Notes}

1 For nonadults under 10 years of age, the actual age-at-death is used instead of the presumed ten years of condition existence.

2 This life table was calculated using vital statistics from late 19th-early 20th century populations from Western and Eastern Europe, Australia, Canada, the United States, Asia, and South Africa (Coale and Demeny 1983), and is the same life table used by Steckel and Rose (2002) in their calculations of health indices from other sites in the Western Hemisphere.

${ }^{3}$ The scoring of the least stressed population included in Steckel and Rose (2002), that of the southern Brazilian Shellmound region (health index rank of 91.8), was skewed by the lack of postcranial remains (Hubbe et al., 2017), and so the value for this group should be discounted. 